Obrady podsumował prof. Marek Wąsowicz. Zauważył, że w środowisku historyczno-prawnym panuje zgoda co do potrzeby prowadzenia dydaktyki w dotychczasowym rozmiarze, istnieją natomiast rozbieżności w kwestiach metodycznych. Przypomniał, że publikacje z zakresu historii prawa są czytane nie tylko przez prawników-dogmatyków, ale i przez przedstawicieli wielu innych dziedzin, oraz wyraził nadzieję, że każde badanie historyczne może - nawet w sposób niespodziewany dla autora - okazać się współcześnie przydatne.

Jubileuszowa sesja Instytutu Historii Prawa UW stała się okazją do wymiany poglądów i doświadczeń tyczących roli historii prawa jako dyscypliny naukowej i jej miejsca w dydaktyce studiów prawniczych. Dobrze się stało, że po raz kolejny w swej sześćdziesięcioletniej historii Instytut mógł takiej dyskusji patronować. Miejmy też nadzieję, że stanie się ona asumptem do dalszych rozważań, łączących harmonijnie naukę i dydaktykę historii prawa.

PIOTR POMIANOWSKI (Warszawa)

\title{
MIĘDZYNARODOWA NAGRODA NAUKOWA IM. JULIUSZA BARDACHA
}

Instytut Wielkiego Księstwa Litewskiego (IWKL), usytuowany przy Uniwersytecie im. Witolda Wielkiego w Kownie, mający charakter międzynarodowy, ustanowił nagrodę im. Prof. Juliusza Bardacha, wybitnego polskiego historyka prawa, uznanego w świecie lituanisty, doktora honoris causa m.in. Uniwersytetu Wileńskiego.

Nagroda - wedle ogłoszonego regulaminu - przyznawana będzie (od jej pierwszej edycji w 2013 r.) za prace doktorskie i magisterskie (lub równoważne), w których ujęto badania nad polityczno-ustrojowym, prawnym i kulturowym dziedzictwem Wielkiego Księstwa Litewskiego, przejawami tradycji Wielkiego Księstwa Litewskiego w XIX i XX w. bądź podjęto tematy współczesne: władzy i polityki na terytoriach byłego Wielkiego Księstwa - Białorusi, Litwy, Ukrainy oraz Polski w historycznym kontekście. Prace mogą obejmować różne sfery nauk humanistycznych, więc obok historii oraz historii ustroju i prawa, także politologię, filologię, socjologię i geografię.

Instytut Wielkiego Księstwa Litewskiego - firmujący nagrodę im. Juliusza Bardacha - został powołany 26 listopada 2009 r. z udziałem osób prawnych (instytucji państwowych i organizacji pozarządowych) oraz osób fizycznych - wybitnych przedstawicieli nauki i życia społecznego z Litwy, Białorusi, Ukrainy i Polski.

Do założycieli IWKL - osób prawnych należą: Uniwersytet Witolda Wielkiego w Kownie (UWW) oraz „Czesław Miłosz Birthplace Foundation” (Šeteniai /Kedainiai/ - Kaunas) - fundacja z siedzibą w Kownie i w Szetejniach (d. powiat kiejdański), więc w miejscu urodzenia Patrona. Jest tu też fundacja „Sigugara” (Kaunas).

Do założycieli indywidualnych - partnerów Instytutu zaliczają się znani, wybitni badacze litewscy: prof. Egidijus Aleksandravičius, dyrektor Instytutu Litewskiej 
Emigracji UWW, prof. Antanas Kulakauskas z Uniwersytetu Michała Romera, doktor honoris causa UWW, prof. Rimantas Miknys - dyrektor Instytut Historii Litwy w Wilnie oraz doc. Andrzej Pukszto z Katedry Politologii Uniwersytetu Kowieńskiego. Stronę polską w tym gronie reprezentują: dyrektor Studium Europy Wschodniej Uniwersytetu Warszawskiego Jan Malicki, zasłużony od więcej niż dwu dekad w organizowaniu i prowadzeniu studiów oraz badań zwłaszcza w zakresie historii i nauk politycznych Europy Środkowo-Wschodniej (wspierany od początku także przez Patrona nagrody), prof. Dariusz Szpoper z Uniwersytetu Gdańskiego (UG), historyk prawa, lituanista, znany badacz dziejów XIX i poł. XX w. (inicjator - dodajmy - nadania wspominanej tu nagrodzie imienia jej Patrona) oraz Małgorzata SporekCzyżewska - dyrektor polskiej fundacji „Pogranicze” z siedzibą w Sejnach (znanej polskiej organizacji pozarządowej, koncentrującej się na promocji wielokulturowości i wzajemnej tolerancji). Są tu też Jacek Jan Komar - znany publicysta, b. dziennikarz „Głosu Wileńskiego" i b. korespondent „Gazety Wyborczej” z Litwy oraz Tomasz Kopoczyński, adwokat z Gdyni.

Instytut Wielkiego Księstwa Litewskiego wybrał Radę Naukową, do której weszli: Andrzej Kozakiewicz, dyrektor politologiczno-badawczego Instytutu ,Polityczna Sfera" w Mińsku (Białoruś), Aleksander Smalańczuk z Europejskiego Humanistycznego Uniwersytetu w Wilnie, profesor Instytutu Historii Białorusi, dr hab. Przemysław Dąbrowski z Katedry Historii Państwa i Prawa Polskiego na Wydziale Prawa UG oraz Igor Cepienda, rektor Przykarpackiego Uniwersytetu Iwana-Franki na Ukrainie.

Do pierwszoplanowych zadań Instytutu należy współpraca naukowa zwłaszcza z ośrodkami badań wschodnioeuropejskich w Europie i na świecie, promowanie międzynarodowej wymiany naukowej i stypendiów badawczych w zakresie także szeroko pojętej lituanistyki, organizowanie Międzynarodowego Kongresu Studiów Białoruskich, wydawanie wraz z Instytutem „Polityczna Sfera” w Mińsku w języku angielskim „Belarusian Political Science Review” oraz realizacja edycji nagrody im. Juliusza Bardacha.

WANDA SUDNIK-BARDACH (Warszawa)

\section{ODNOWIENIE DOKTORATU PROFESORA MARKA WALDENBERGA}

W dniu 17 października 2012 r. w auli Collegium Maius Uniwersytetu Jagiellońskiego w Krakowie odbyło się uroczyste posiedzenie Senatu z okazji odnowienia po 50 latach doktoratu Marka Waldenberga, profesora zwyczajnego w Instytucie Nauk Politycznych i Stosunków Międzynarodowych Wydziału Studiów Międzynarodowych i Politycznych UJ. Profesor jest autorem licznych i thumaczonych na wiele języków publikacji poświęconych międzynarodowej myśli socjalistycznej oraz problematyce narodu, kwestiom narodowym w Europie Środkowo-Wschodniej, zagadnieniom nacjonalizmów, konfliktów etnicznych oraz mniejszościom narodowym. 